\title{
EFFECTS OF SEVERAL TUMOR-INHIBITORY ANTIBIOTICS ON IMMUNOLOGICAL RESPONSES
}

\author{
Hiroshi Yamaki, Nobuo Tanaka and Hamao Umezawa \\ Institute of Applied Microbiology, University of Tokyo, Tokyo, Japan
}

(Received for publication May 20, 1969)

\begin{abstract}
The effects of various tumor-inhibitory antibiotics on immunological responses were investigated, using serum antibody production against human gamma globulin and sheep red cells in mice, development of tuberculin hypersensitivity in guinea pigs, and skin allograft reaction in mice. The effects on antibody-forming cells in the mouse spleen were observed by JERNE's method. Of the antibiotics examined, pluramycin significantly suppressed the immunological responses. The responses of cellular antibodies were more markedly affected than those of circulating antibodies. By the method employed, bleomycin, phenomycin, angustmycins $\mathrm{A}$ and $\mathrm{C} \operatorname{did}$ not exhibit any significant activity of immunosuppression. The skin allograft reaction was not significantly modified by formycins A and B. Pluramycin was observed to inhibit the growth of plasmocytoma in mice.
\end{abstract}

Some mitotic poisons, including methotrexate, 6-mercaptopurine, azathioprine, and cyclophosphamide, exhibit an immunosuppressive activity as well as a tumor-inhibitory activity. It indicates that the immunological responses, i.e. the production of circulating and cellular antibodies, are produced by rapidly proliferating cells.

Immunosuppression is an urgent problem for the prolongation of allograft survival in transplantation and treatment of allergic and autoimmune diseases. On the contrary, the immunosuppressive activity of antitumor drugs seems to be generally unfavorable for the treatment of malignant neoplasma. From these points of view, the effects of several tumor-inhibitory antibiotics on various forms of immunological responses were investigated. The results are presented in this publication. Furthermore, the activity against growth of plasmocytoma was examined.

\section{Materials and Methods}

Angustmycin A (decoyinine) and angustmycin C (psicofuranine) were obtained through the courtesy of Dr. G. B. Whitrield, the Upjohn Company, Kalamazoo, Michigan, U. S. A. Phenomycin was supplied by Dr. S. Nakamura, Institute of Applied Microbiology, University of Tokyo, Tokyo. Methotrexate, 6-mercaptopurine, and cyclophosphamide were products of Lederle Laboratories, Kokoku Rayon and Pulp Co., and Shionogi Co. respectively. Pluramycin, bleomycin $\mathrm{A}_{2}$ and formycins $\mathrm{A}$ and $\mathrm{B}$ were from Institute of Microbial Chemistry.

Antibody responses to sheep erythrocytes in mice ${ }^{1)}$ : Male mice of the $D D D$ strain, weighing $20 \sim 25 \mathrm{~g}$, were employed. Groups of 5 to 10 mice were immunized with $2 \times 10^{8}$

The abbreviations of drugs used are: Ang A, angustmycin A; Ang C, angustmycin C; BLM, bleomycin; CY, cyclophosphamide; FM-A, formycin A; FM-B, formycin B; 6MP, 6-mercaptopurine; MTX, methotrexate; PC, Penicillin; PhM, phenomycin; PLM, pluramycin; SM, streptomycin. 
washed sheep red cells intravenously via the tail vein. Drugs were administered intraperitoneally for 4 successive days immediately or 2 days after immunization. Antisera were pooled together in each group. The hemagglutination test was performed in serial two-fold dilutions of $0.5 \mathrm{ml}$ in $\mathrm{pH} 7.2$ buffered saline, containing $1 / 100$ normal rabbit serum, to which $0.3 \mathrm{ml}$ of $0.3 \%$ washed sheep red cells were added. The hemagglutinin titers were expressed by the final dilution of antiserum. The tubes were shaken and allowed to stand for 4 hours at room temperature. The antibody activity of serum was fractionated into $7 \mathrm{~S}$ and $19 \mathrm{~S}$ antibodies by $0.1 \mathrm{M} 2$-mercaptoethanol treatment ${ }^{2)}$.

The hemolytic plaque test of antibody-forming cells was carried out according to the method of JERne et al. ${ }^{3)}$.

Antibody production for human gamma globulin in mice: $D D D$ male mice, weighing $20 \sim 25 \mathrm{~g}$, were used. Groups of 5 to 10 mice were injected with human gamma globulin $(2 \mathrm{mg} / \mathrm{kg})$ subcutaneously in the inguinal region, and sera were collected on the 17 th day. In the case of the secondary response, human gamma globulin $(2 \mathrm{mg} / \mathrm{kg})$ was injected once more 4 weeks after the primary stimulus. The animals were bled 8 days later. Antibody titers were determined by the passive hemagglutination test of BoyDEN ${ }^{4,5}$.

Tuberculin reaction in guinea pigs $^{6,7)}$ : Albino guinea pigs of the Hartley strain, weighing $270 \sim 320 \mathrm{~g}$, were sensitized by intramuscular injection of liquid paraffin Bayol $\mathrm{F}$ with $15 \%$ Arlacel, containing $100 \mu \mathrm{g}$ of autoclaved dry bacilli of Mycobacterium tuber culosis Aoyama B. Drugs were administered intraperitoneally 5 times within the 4 th to the 5 th week. Animals were tested intradermally on the back with $2 \mu \mathrm{g} / 0.1 \mathrm{ml}$ of PPD, a tuberculoprotein. The reactions were observed and areas of erythema were measured at 12, 24, 48, 72 and 96 hours. PPD was kindly supplied by Dr. N. Asami, National Institute of Health, Tokyo.

Skin grafting procedure ${ }^{9)}: D D D$ mice were used as recipients, and $F_{1}$ hybrids between $D D D$ and $C 3 H / H e$ as donors. Skin grafts were performed according to the technique of Billingham and $\mathrm{MedawaR}^{8)}$. The grafts were followed by visual and tactile inspection until graft destruction was $50 \%$, and the median survival time of the grafts at $50 \%$ destruction was assessed with determination of standard error in a group of 10 recipient mice. Drugs were injected intraperitoneally for 2 weeks after skin grafting.

Transplantation of mouse plasmocytoma X556310) $\mathrm{C} 3 \mathrm{H} / \mathrm{He}$ male mice were inoculated intraperitoneally with $3 \times 10^{6}$ plasmocytoma X5563 cells and treated once daily for 7 days by intraperitoneal adminitsration of drugs, starting 6 hours after the inoculation of tumor cells.

\section{Results}

\section{Effects of Antibiotics on Primary and Secondary Responeses to Human Gamma Globulin}

The hemagglutinin titer of control animals was $1: 320$ in the primary response 16 days after the injection of antigen and $1: 6,400$ in the secondary response 8 days after the second antigen stimulus. Pluramycin suppressed antibody formation with a titer of $1: 160$ in the primary response and $1: 3,200$ in the secondary response by the intraperitoneal administration of daily $8 \mathrm{mg} / \mathrm{kg}$ for 4 days. It inhibited the production of 2-mercaptoethanol sensitive antibody, but not that of 2-mercaptoethanol resistant antibody. Bleomycin at a dosage of $20 \mathrm{mg} / \mathrm{kg} /$ day did not exhibit significant effects on the antibody responses. Methotrexate, cyclophosphamide, and 6-mercaptopurine showed more marked suppression than pluramycin. The results are summarized in Table 1. 
Table 1. Effects of drugs on primary and secondary responses to human gamma globulin Primary response

\begin{tabular}{|c|c|c|c|}
\hline \multirow{2}{*}{$\begin{array}{c}\text { Drugs } \\
\mathrm{mg} / \mathrm{kg} / \text { day }\end{array}$} & \multicolumn{2}{|c|}{ Antibody titer (ratio) } & \multirow{2}{*}{$\begin{array}{l}\text { Toxicity } \\
\text { (mice } \\
\text { survived) }\end{array}$} \\
\hline & Total antibody & $\begin{array}{l}\text { 2-ME resist- } \\
\text { ant antibody }\end{array}$ & \\
\hline Control & $320(1)$ & $160(1)$ & $5 / 5$ \\
\hline $6 \mathrm{MP} \quad 80 \times 4$ & $160(1 / 2)$ & $80 \quad(1 / 2)$ & $5 / 5$ \\
\hline $50 \times 4$ & $80 \quad(1 / 4)$ & $40 \quad(1 / 4)$ & $5 / 5$ \\
\hline MTX $2 \times 4$ & $160(1 / 2)$ & $160(1)$ & $5 / 5$ \\
\hline PLM & $160(1 / 2)$ & 160 ( 1$)$ & $5 / 5$ \\
\hline BLM $20 \times 4$ & $320(1)$ & 160 ( 1 ) & $5 / 5$ \\
\hline
\end{tabular}

Secondary response

\begin{tabular}{l|c|c}
\hline $\begin{array}{c}\text { Drugs } \\
\mathrm{mg} / \mathrm{kg} / \text { day }\end{array}$ & $\begin{array}{c}\text { Antibody } \\
\text { titer } \\
\text { (ratio) }\end{array}$ & $\begin{array}{l}\text { Toxicity } \\
\text { (mice } \\
\text { survived) }\end{array}$ \\
\hline Control & $6,400(1)$ & $10 / 10$ \\
6MP $80 \times 4$ & $3,200(1 / 2)$ & $10 / 10$ \\
CY $50 \times 4$ & $400(1 / 16)$ & $10 / 10$ \\
MTX $2 \times 4$ & $3,200(1 / 2)$ & $10 / 10$ \\
PLM $8 \times 4$ & $3,200(1 / 2)$ & $10 / 10$ \\
BLM $20 \times 4$ & $6,400(1)$ & $10 / 10$ \\
\hline
\end{tabular}

The antigen was subcutaneously injected and the drugs were intraperitoneally administered.

Antibody titer was determined by Boyden's method. Figures in brackets represent relative titers.

\section{Effects of Antibiotics on the Response of Serum Antibody to Sheep Red Cells}

The response of serum antibody to sheep red cells was inhibited by pluramycin. A single dose of $8 \mathrm{mg} / \mathrm{kg}$ gave 16 or 32 times lower titers than the control. By the method employed, no significant effects were observed with bleomycin, angustmycins A and C, and phenomycin. Significant inhibition was demonstrated with 6-mercaptopurine, cyclophosphamide, and methotrexate. The results are shown in Table 2.

The production of antibody-forming cells, demonstrated by JERNE's method was inhibited by pluramycin. In control animals, $2.1 \times 10^{4}$ hemolytic plaques on the average were formed in the spleen. The number of hemolytic plaques was reduced to $1.38 \times 10^{4}$ per spleen by a single injection of pluramycin $(8 \mathrm{mg} / \mathrm{kg})$ on the second day after immunization. No significant suppression was observed with bleomycin, angust-

Table 2. Effects of drugs on antibody response to sheep erythrocytes

\begin{tabular}{|c|c|c|c|c|}
\hline \multirow{2}{*}{\multicolumn{2}{|c|}{$\begin{array}{c}\text { Drugs } \\
\mathrm{mg} / \mathrm{kg} / \text { day }\end{array}$}} & \multicolumn{2}{|c|}{ Hemagglutinin titers } & \multirow{2}{*}{$\begin{array}{c}\text { Mice } \\
\text { survived }\end{array}$} \\
\hline & & $I^{*}$ & II * & \\
\hline \multicolumn{2}{|c|}{ Control } & $2,048(1) * *$ & $2,048(1)$ & $10 / 10$ \\
\hline $6 \mathrm{MP}$ & $\begin{array}{r}320 \times 1 \\
80 \times 4\end{array}$ & $\begin{array}{l}2,048(1) \\
1,024(1 / 2)\end{array}$ & $\begin{array}{l}64(1 / 32) \\
64(1 / 32)\end{array}$ & $\begin{array}{l}10 / 10 \\
10 / 10\end{array}$ \\
\hline $\mathrm{CY}$ & $80 \times 4$ & $128(1 / 16)$ & $64(1 / 32)$ & $9 / 10$ \\
\hline MTX & $\begin{array}{l}8 \times 4 \\
2 \times 4\end{array}$ & $\begin{array}{r}64(1 / 32) \\
512(1 / 4)\end{array}$ & $\begin{array}{r}128(1 / 16) \\
1,024(1 / 2)\end{array}$ & $\begin{array}{l}10 / 10 \\
10 / 10\end{array}$ \\
\hline PLM & $\begin{array}{l}8 \times 1 \\
2 \times 4\end{array}$ & $\begin{aligned} 64 & (1 / 32) \\
2,048 & (1)\end{aligned}$ & $\begin{aligned} 128(1 / 16) \\
2,048(1)\end{aligned}$ & $\begin{array}{r}10 / 10 \\
9 / 10\end{array}$ \\
\hline BLM & $\begin{array}{l}50 \times 1 \\
10 \times 4\end{array}$ & $\begin{array}{l}2,048(1) \\
2,048(1)\end{array}$ & $\begin{array}{l}2,048(1) \\
2,048(1)\end{array}$ & $\begin{array}{l}10 / 10 \\
10 / 10\end{array}$ \\
\hline Ang $A$ & $1000 \times 4$ & $2,048(1)$ & $2,048(1)$ & $10 / 10$ \\
\hline Ang $C$ & $1000 \times 4$ & $2,048(1)$ & $2,048(1)$ & $10 / 10$ \\
\hline $\mathrm{PhM}$ & $\begin{array}{l}0.5 \times 4 \\
0.1 \times 4\end{array}$ & $\begin{array}{l}2,048(1) \\
2,048(1)\end{array}$ & $\begin{array}{l}2,048(1) \\
2,048(1)\end{array}$ & $\begin{array}{l}10 / 10 \\
10 / 10\end{array}$ \\
\hline
\end{tabular}

* The drug administration started immediately (column I) or 2 days (column II) after the injection of sheep red cells.

** The values represent hemagglutinin titers in the 2nd week after the immunization, and the figures in the brackets relative titers.
Table 3. Effects of drugs on the antibody-forming activity of mouse spleen cells, observed by JERNE's method.

\begin{tabular}{lr|l|l}
\hline \multicolumn{2}{c|}{$\begin{array}{l}\text { Drugs } \\
\mathrm{mg} / \mathrm{kg} / \text { day }\end{array}$} & Cells/spleen & $\begin{array}{c}\text { Plaque- } \\
\text { forming } \\
\text { cells/spleen }\end{array}$ \\
\hline Control & & $1.52 \times 10^{7}$ & $210 \times 10^{2}$ \\
$6 \mathrm{MP}$ & $320 \times 1$ & 2.54 & 78 \\
& $80 \times 2$ & 1.38 & 79 \\
$\mathrm{CY}$ & $80 \times 2$ & 1.02 & 1 \\
MTX & $8 \times 2$ & 1.65 & 65 \\
& $2 \times 2$ & 2.84 & 340 \\
PLM & $8 \times 1$ & 0.75 & 138 \\
& $2 \times 2$ & 1.01 & 201 \\
BLM & $0.5 \times 2$ & 2.57 & 819 \\
& $10 \times 1$ & 1.89 & 253 \\
Ang A & $200 \times 2$ & 1.66 & 364 \\
Ang C & $200 \times 2$ & 1.39 & 248 \\
\hline
\end{tabular}

Sheep red blood cells were intravenously injected and the drugs were intraperitoneally administered, starting 2 days after immunization. 
mycins A and C. Marked suppression was demonstrated with 6-mercaptopurine, cyclophosphamide, and methotrexate. The results are presented in Table 3.

The Effect on Growth of Mouse

Plasmocytoma X5563 of Ascitic Form

The effects of drugs were evaluated by the survival time of $\mathrm{C} 3 \mathrm{H} / \mathrm{He}$ mice bearing plasmocytoma X5563 of ascitic form. The mean survival time of control animals was $14.8 \pm 0.9$ days. Pluramycin prolonged the survival time. The effect was observed to be less than 6-mercaptopurine and cyclophosphamide, but higher than methotrexate. Bleomycin and angustmycins exhibited no significant activity on plasmocytoma of ascitic form. The results are presented in Table 4 and Fig. 1. The activity of antibiotics showed a certain parallelism to that on antibody formation.
Table 4. Effects of drugs on growth of mouse plasmocytoma X 5563 of ascitic form

\begin{tabular}{lc|c}
\hline Drugs & $\mathrm{mg} / \mathrm{kg} / \mathrm{day}$ & $\begin{array}{c}\text { Relative } \\
\text { survival time }\end{array}$ \\
\hline Control & & 1.00 \\
$6 \mathrm{MP}$ & $80 \times 10$ & 3.68 \\
& $20 \times 10$ & 2.62 \\
CY & $20 \times 10$ & 2.84 \\
& $5 \times 10$ & 3.65 \\
MTX & $2 \times 10$ & 1.32 \\
& $0.5 \times 10$ & 1.02 \\
PLM & $0.1 \times 10$ & 1.01 \\
& $0.5 \times 8$ & 1.50 \\
BLM & $0.1 \times 10$ & 1.60 \\
& $0.5 \times 10$ & 1.01 \\
Ang A & $200 \times 10$ & 1.16 \\
Ang C & $200 \times 10$ & 1.41 \\
\end{tabular}

Plasmocytoma X5563 cells were inoculated into the peritoneal cavity of $\mathrm{C} 3 \mathrm{H} / \mathrm{He}$ mice. The mean survival time of controls was $14.8 \pm 0.9$ days. Drugs were intraperitoneally administered, starting 6 hours after the inoculation, and the effects were evaluated by prolongation of survival time.

The Effects of Pluramycin on the Development of

Tuberculin Hypersensitivity in Guinea Pigs

As shown in Table 5, pluramycin was observed to suppress the development of tuberculin hypersensitivity in guinea pigs, which had been injected with dry cells of Mycobacterium tuberculosis Aoyama B in mineral oil 6 weeks before. In controls the average diameter of erythema was $17.8 \pm 0.5 \mathrm{~mm} 24$ hours af ter the intradermal injection of $2 \mu \mathrm{g}$ PPD, a tuberculoprotein. The skin reaction was reduced to $5.5 \pm 2.2 \mathrm{~mm}$ by treatment with pluramycin in the dose of $0.5 \mathrm{mg} / \mathrm{kg} \times 5$ and to $10.0 \pm 0.2 \mathrm{~mm}$ in the dose of $0.1 \mathrm{mg} / \mathrm{kg} \times 5$.
Table 5. Effects of pluramycin on the development of delayed hypersensitivity in guinea pigs, inoculated with dry bacilli of Mycobacterium tuberculosis Aoyama B in mineral oil

\begin{tabular}{|c|c|c|c|c|}
\hline \multirow{3}{*}{ Drug } & \multicolumn{3}{|c|}{ Skin reaction } & \multirow{3}{*}{ Survival } \\
\hline & \multicolumn{2}{|c|}{$\begin{array}{l}\text { Diameter of } \\
\text { erythems }(\mathrm{mm})\end{array}$} & \multirow{2}{*}{$\begin{array}{l}\text { Degree of } \\
\text { induration }\end{array}$} & \\
\hline & $12 \mathrm{hrs}$ & $24 \mathrm{hrs}$ & & \\
\hline Control & $\begin{array}{l}16 \times 15 \\
15 \times 15 \\
17 \times 20 \\
17 \times 20 \\
18 \times 13 \\
16 \times 17\end{array}$ & $\begin{array}{l}17 \times 15 \\
13 \times 18 \\
20 \times 20 \\
19 \times 17 \\
16 \times 18 \\
18 \times 16\end{array}$ & $\begin{array}{l}+++ \\
+++ \\
+++ \\
+++ \\
+++ \\
+++\end{array}$ & $6 / 6$ \\
\hline $\mathrm{PLM} \quad 0.5 \mathrm{mg} / \mathrm{kg} \times 5$ & $\begin{array}{c}0 \\
0 \\
10 \times 10 \\
12 \times 12\end{array}$ & $\begin{array}{c}0 \\
0 \\
14 \times 14 \\
10 \times 13\end{array}$ & $\begin{array}{l}- \\
\overline{+} \\
+\end{array}$ & $4 / 4$ \\
\hline PLM $0.1 \mathrm{mg} / \mathrm{kg} \times 5$ & $\begin{array}{r}10 \times 10 \\
10 \times 9 \\
9 \times 10 \\
10 \times 10\end{array}$ & $\begin{array}{r}10 \times 10 \\
9 \times 9 \\
13 \times 10 \\
10 \times 10\end{array}$ & $\begin{array}{l}+ \\
+ \\
+ \\
+\end{array}$ & $4 / 4$ \\
\hline
\end{tabular}

Pluramycin was intraperitoneally injected 5 time from the 30 th to the 39 th day (every other day) after the injection of tubercle bacilli in mineral oil. Tuberculin reactions were observed 12 and 24 hours after the intradermal injection of $2 \mu \mathrm{g} / 0.1 \mathrm{ml}$ of tuberculoprotein PPD. 
The Effects of Antibiotics on the

Survival of Skin Allograft

The skin of $\mathrm{F}_{1}$ hybrids of $\mathrm{C} 3 \mathrm{H} / \mathrm{He} \times$ $D D D$ was transplanted in $D D D$ mice. The mean skin survival was $22.6 \pm 2.7$ days. Pluramycin markedly prolonged the skin survival, and a survival of $40.7 \pm 3.7$ days was observed, when the antibiotic was administered daily in a dosage of $0.2 \mathrm{mg} / \mathrm{kg}$ for 16 days, starting on the day of skin transplantation. A survival of $30.7 \pm 5.3$ or $36.1 \pm 5.0$ days could be demonstrated with the dosage of 0.5 or $0.1 \mathrm{mg} / \mathrm{kg} /$ day when the treatment was started on the 4 th day and continued for 12 days. Methotrexate and cyclophosphamide exhibited less prolongation of skin allograft survival in the simultaneous experiments. No significant effects were observed with 6-mercaptopurine,

Table 6. Effects of antibiotics on the survival of skin allograft. I

\begin{tabular}{cc|c|c}
\hline \multicolumn{2}{c|}{$\begin{array}{c}\text { Drugs } \\
\mathrm{mg} / \mathrm{kg} / \text { day }\end{array}$} & $\begin{array}{c}\text { Mean skin } \\
\text { survival time }\end{array}$ & $\begin{array}{c}\text { Mouse } \\
\text { survived }\end{array}$ \\
\hline Control & $22.6 \pm 2.7(100)$ & $46 / 46$ \\
6MP & 80 & $23.0 \pm 1.7(103)$ & $10 / 10$ \\
& 20 & $20.0 \pm 2.4(85)$ & $10 / 10$ \\
CY & 100 & $28.2 \pm 2.2(125)$ & $6 / 10$ \\
& 20 & $20.0 \pm 5.3(85)$ & $9 / 10$ \\
MTX & 2 & $38.0 \pm 4.5(168)$ & $10 / 10$ \\
& 0.5 & $21.7 \pm 3.0(96)$ & $10 / 10$ \\
PLM & 0.5 & $25.1 \pm 2.2(112)$ & $9 / 10$ \\
& 0.2 & $40.7 \pm 3.7(180)$ & $10 / 10$ \\
& 0.1 & $30.0 \pm 3.3(132)$ & $10 / 10$ \\
Ang A & 200 & $23.0 \pm 3.1(102)$ & $10 / 10$ \\
& 50 & $23.6 \pm 1.7(108)$ & $10 / 10$ \\
Ang C & 200 & $23.9 \pm 1.0(78)$ & $10 / 10$ \\
& 50 & $22.2 \pm 2.4(103)$ & $10 / 10$ \\
BLM & 10 & $15.9 \pm 1.2(71)$ & $10 / 10$ \\
& 2 & $20.3 \pm 2.8(90)$ & $7 / 10$ \\
PhM & 0.5 & $20.7 \pm 1.0(92)$ & $10 / 10$ \\
& 0.1 & $26.6 \pm 1.9(118)$ & $9 / 10$ \\
FM-A & 50 & $22.3 \pm 2.1(94)$ & $8 / 10$ \\
& 10 & $19.1 \pm 2.7(81)$ & $10 / 10$ \\
FM-B & 500 & $15.9 \pm 1.6(67)$ & $7 / 10$ \\
& 100 & $12.6 \pm 1.5(53)$ & $8 / 10$ \\
SM & 20 & $21.3 \pm 3.0(94)$ & $10 / 10$ \\
PC & 10 & $24.7 \pm 2.5(109)$ & $10 / 10$ \\
\hline
\end{tabular}

The skin of $\mathrm{F}_{1}$ hybrid of $\mathrm{C} 3 \mathrm{H} / \mathrm{He}$ and $\mathrm{DDD}$ was transplanted in $D D D$ mice. Drugs were administered daily for 16 days, starting on the day of skin transplantation.
Fig. 1. Effects of drugs on growth of mouse plasmocytoma X5563 of ascitic form. Percent survival after inoculation of plasmocytoma cells.
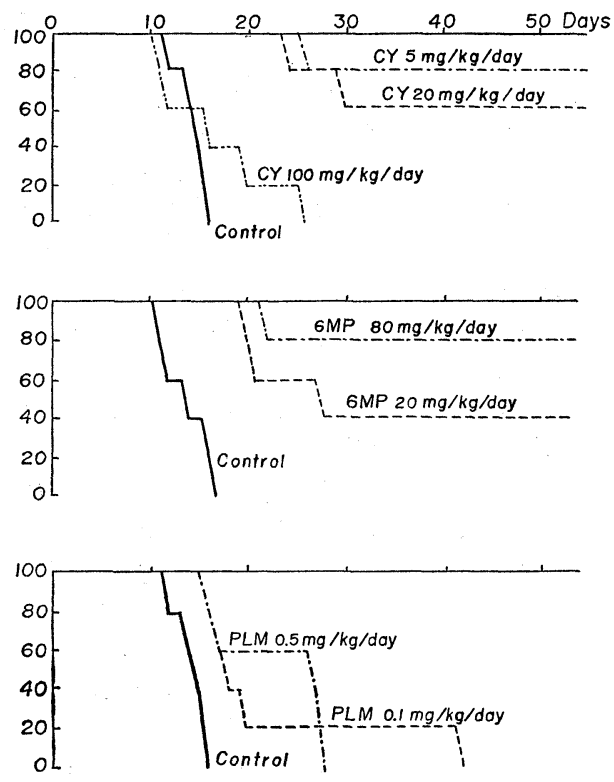

Table 7. Effects of antibiotics on the survival of skin allograft. II

\begin{tabular}{lc|c|c}
\hline \multicolumn{2}{c|}{$\begin{array}{c}\text { Drugs } \\
\mathrm{mg} / \mathrm{kg} / \text { day }\end{array}$} & $\begin{array}{c}\text { Mean skin } \\
\text { survival time }\end{array}$ & $\begin{array}{c}\text { Mouse } \\
\text { survived }\end{array}$ \\
\hline \multirow{2}{*}{ Control } & & $22.6 \pm 2.7(100)$ & $46 / 46$ \\
6MP & 80 & $24.7 \pm 1.7(109)$ & $10 / 10$ \\
& 20 & $22.2 \pm 1.7(98)$ & $10 / 10$ \\
& 5 & $20.0 \pm 2.5(88)$ & $10 / 10$ \\
CY & 100 & $33.6 \pm 4.3(148)$ & $8 / 10$ \\
& 20 & $30.9 \pm 4.1(136)$ & $10 / 10$ \\
& 5 & $24.5 \pm 3.2(108)$ & $10 / 10$ \\
PLM & 0.5 & $30.7 \pm 5.3(135)$ & $9 / 10$ \\
& 0.1 & $36.1 \pm 5.0(159)$ & $10 / 10$ \\
& 0.05 & $21.7 \pm 2.9(96)$ & $10 / 10$ \\
Ang A & 50 & $25.8 \pm 2.5(115)$ & $10 / 10$ \\
& 5 & $16.0 \pm 1.7(71)$ & $10 / 10$ \\
Ang C & 200 & $26.7 \pm 1.9(118)$ & $10 / 10$ \\
& 50 & $21.5 \pm 1.7(95)$ & $10 / 10$ \\
BLM & 10 & $29.7 \pm 3.7(131)$ & $10 / 10$ \\
& 2 & $31.6 \pm 3.8(140)$ & $10 / 10$ \\
PhM & 0.5 & $16.1 \pm 1.4(71)$ & $10 / 10$ \\
& 0.1 & $30.1 \pm 3.1(133)$ & $10 / 10$ \\
& & & \\
\hline
\end{tabular}

The skin of $\mathrm{F}_{1}$ hybrid of $\mathrm{C} 3 \mathrm{H} / \mathrm{He}$ and $D D D$ was transplanted in $D D D$ mice. Drugs were administered daily for 12 days, starting on the 4 th day after skin transplantation. 
augustmycins $\mathrm{A}$ and $\mathrm{C}$, bleomycin, phenomycin, and formycins $\mathrm{A}$ and $\mathrm{B}$. The results are shown in Tables 6 and 7 .

\section{Discussion}

Of the tumor-inhibitory antibiotics examined, pluramycin was observed to suppress the immunological responses. The responses of cellular antibody, such as tuberculin hypersensitivity and skin allograft reaction, were more markedly inhibited than the production of circulating antibody. On the contrary, angustmycins $\mathrm{A}$ and $\mathrm{C}$, bleomycin, and phenomycin did not significantly influence the immunological responses. By the method employed, formycins A and B exhibited no significant activity on skin allograft reaction. The results indicate that these antitumor agents have different modes of action in their immunosuppressive activity.

Pluramycin interacts with DNA, obtained from calf thymus, mouse plasmocytoma, and other mammalian cells, as well as with bacterial DNA. It inhibits DNA and RNA syntheses and secondarily affects protein synthesis in intact cells to a smaller extent ${ }^{11,12)}$. Compounds, such as pluramycin, methotrexate, cyclophosphamide, and 6-mercaptopurine, reacting with DNA or inhibiting its synthesis suppress the immunological responses more markedly than inhibitors of protein synthesis, such as phenomycin ${ }^{13)}$. This suggests that they interfere with mitosis or cell division and differentiation of immunologically competent cells and hence suppress immunological responses.

The primary action of bleomycin in neoplasmic cells seems to be its binding to $\mathrm{DNA}^{14,15)}$. Pluramycin and bleomycin show different modes of activity on immunological responses, although both antibiotics exhibit antitumor activity by binding to DNA. Differences in immunosuppressive activity of antitumor agents may depend on tissue distribution and metabolism in vivo and their transport into the immunologically competent cells, as well as on their activity on cell division and differentiation. The diverse immunosuppressive activity of antitumor agents may be interpreted as a difference of transport and metabolism in the body. The lacking of immunosuppressive effects from bleomycin may be due to inactivation of this antibiotic in the cells concerning production of circulating and cellular antibodies. It may be important in cancer chemotherapy that bleomycin exhibits no significant immunosuppressive activity on either cellular or circulating antibody responses.

The differential inhibition by pluramycin of circulating and cellular antibody responses seems to be related to different mechanisms or cells involved in these two types of antibody responses. The antibiotic suppresses both responses, although to a different extent. This also suggests that DNA-dependent DNA and/or RNA syntheses, which are sensitive to pluramycin, are involved in both forms of antibody responses.

The site of action of angustmycins and formycins seems to be in purine nucleotide de novo synthesis ${ }^{16 \sim 18)}$. These antibiotics lack immunosuppressive activity, although 6 -mercaptopurine, also an inhibitor of purine nucleotide biosynthesis, exbibits a marked immunosuppressive activity. The difference in the activity may be due to the mechanism discussed above.

\section{Acknowledgement}

The authors express their deep thanks to Prof. T. Yамамото, Prof. Y. Ishiвashi, and Dr. K. Ashikawa, Institute of Medical Science, University of Tokyo for their valuable advice and help in performing the experiments of skin graft and plasmocitoma. They are also indebted to Dr. T. Akryama, Department of Microbiology, Keio University School of Medicine for his kind assistance in carrying out Jerne's method, and to Drs. N. Asami, N. Sato, and T. Kataoka for their kind help in tuberculin reaction. 


\section{References}

1) Nathan, H. C.; S. Bieber, G. B. Elion \& G. H. Hitceings : Detection of agents which interfere with the immune response. Proc. Soc. Exp. Biol. \& Med. $107: 796 \sim 799,1961$

2) Deutsch, H. F. \& J. I. Morton: Dissociation of human serum macroglobulins. Science 125 : $600 \sim 601,1957$

3) Jerne, N. K. \& A. A. Nordin : Plaque formation in agar by single antibody-producing cells. Science $140: 405 \sim 406,1963$

4) Boyden, S. V.: The adsorption of proteins on erythrocytes treated with tannic acid and subsequent hemagglutination by antiprotein sera. J. Exp. Med. $93: 107 \sim 120,1951$

5) Stavitsky, A. B. : Micromethods for the study of proteins and antibodies. I. Procedure and general applications of hemagglutination and hemagglutination-inhibition reactions with tannic acid and protein-treated red blood cells. J. Immunol. $72: 360 \sim 367,1954$

6) Hoyer, J. R.; L. W. Hoyer, R. A. Good \& R. M. Condie : The effect of 6-mercaptopurine on delayed hypersensitivity in guinea pigs. J. Exp. Med. $116: 679 \sim 685,1962$

7) Friedman, R. M.; C. E. Buckler \& S. Baron : The effect of aminomethylpteroylglutamic acid on the development of skin hypersensitivity and antibody formation in guinea pigs. J. Exp. Med. $114: 173 \sim 183,1961$

8) Billingham, R. E. \& P. B. Medawar: The technique of free skin grafting in mammals. J. Exp. Biol. $28: 385 \sim 402,1951$

9) Monaco, A. P.; M. L. Wood \& P. S. Russell : Studies on heterologous anti-lymphocyte serum in mice. III. Immunologic tolerance and chimerism produced across the H-2 locus with adult thymectomy and anti-1ymphocyte serum. Ann. N. Y. Acad. Sci. $129: 190 \sim 209,1966$

10) Takeuchi, M. \& T. Yамамото : Effect of bleomycin on mouse transplantable tumors. J. Antibiotics $21: 631 \sim 637,1968$

11) Tanaka, N.; K. NagaI, H. Yamaguchi \& H. Umezawa : Inhibition of RNA and DNA polymerase reactions by pluramycin A. Biochem. Biophys. Res. Commun. $21: 328 \sim 332,1965$

12) NAGAI, K.; H. YAMAKI, N. TANaKa \& H. UmezaWA : Inhibition by pluramycin A of nucleic acid biosynthesis. J. Biochem. $62: 321 \sim 327,1967$

13) Nishimura, T. : Mechanism of action of phenomycin, a tumor-inhibitory polypeptide. J. Antibiotics $21: 110 \sim 118,1968$

14) Suzuki, H.; K. Nagai, H. Yamaki, N. Tanaka \& H. Umezawa : Mechanism of action of bleomycin. Studies with the growing culture of bacterial and tumor cells. J. Antibiotics $21: 379$ $\sim 386,1968$

15) Nagai, K.; H. Yamaki, H. Suzuki, N. Tanaka \& H. Umezawa: The combined effects of bleomycin and sulfhydryl compounds on the thermal denaturation of DNA. Biochim. Biophys. Acta $179: 165 \sim 171,1969$

16) Tanaka, N. : Mechanism of action of angustmycins, nucleoside antibiotics. J. Antibiotics 16 : 163 166, 1963

17) Donovan, K. L.; J. A. Rowe \& H. S. Moyed : Adenine glycoside site of xanthosine-5'-phosphate aminase. Antimicr. Agents \& Chemoth.-1967:289 296, 1968

18) Henderson, J. F.; A. R. P. Paterson, I. C. Caldwell \& M. Hori : Biochemical effects of formycin, an adenosine analogue. Cancer Res. $27: 715 \sim 719,1967$ 